\title{
International folklore reflected in the novels
}

\author{
Tosheva Nilufar ${ }^{1}$ \\ ${ }^{I}$ Tashkent State University of the Uzbek language and literature, Uzbekistan \\ Email:tosheva_n@umail.uz
}

\begin{abstract}
This paper investigates major points of the international folklore. On this case, reflected novels are mentioned and analysed while getting evidences from Uzbekistan. Recieved information is stated for there futher research analyses and outcomed were mentioned as a conlcusion of the research.
\end{abstract}

Keywords: International folklore, folklore, novels, Uzbekistan.

\section{INTRODUCTION}

The links between folklore and written literature in contemporary world literary studies is one of the pressing topics of today's literature. The influence of oral literature on the written literature and the aspiration of the writer to navigate in the use of folk traditions give the peculiarity of the artistic skill.

In recent years, world literary studies and folklore have developed new theoretical perspectives on the interrelation of folklore and written literature, the poetic functions of folklore motives in artistic prose. The connection between folklore and written literature in world literature began many years ago. Studying the motives of folklore in Uzbek literary studies was influenced by Russian literary criticism(Jianzhong \& Stuart, 1996).

The works of folklore are very popular in world literature. At the same time, the creators were inspired by the motives, epic images, rhetoric and art forms of folklore. In many works the expression style, visual means, rituals and ceremonies of the folklore are reflected. Under the influence of folklore in the world literature, "Shahnameh" by Abulcasim Firdavsi, "Faust" by J.V Goethe of "Hamsa" by Alisher Navoi, literary fairy tales of Pushkin and other masterpieces are created.

The connection between written literature and folklore has become a tradition. The folklore embedded in the written literature reflects the same folk spirit and traditions, so the work created under the influence of folklore will be an eternal work. Such works are unique in their international writing style(Song \& Lin, 2010; Tao, Kaplan, \& Omenetto, 2012).

The novel differs from other eternal genres by its style and size.

"The novel is a sizeable, broad portrayal of life, the protagonist's long life, and his interpretation of various social relationships, reflecting the current state of society through the fate of many and diverse people; genre features such as having a multi-line plot."

The study of the genre of the novel has its own complexities of study and scientific analysis by the world literary scholars M. Iyxenbaum, Yu. Tinyanov, M. Bakhtin, I. Meletinsky and others. The peculiarities and characters of this genre vary widely in their creative work, but the content of the novel reflects the national spirit of the people in which the genre is told. This nationality is constantly changing in relation to the international times, times and times.

"The first component in the genre of literary genres that determines the originality of the novel is the prevailing thinking inherent in the novel. Therefore, the analysis of the novel's genre is an analysis of the artistic aesthetics of society. "

Indeed, in the novel reflecting the artistic and aesthetic thinking of society, its role is to increase the internationalization of the genre by engaging in customs, traditions, rituals, proverbs, folk expressions, folk epics and other folklore. The national spirit in the novels of the writer Isajon Sultan came from folklore motives involved in the work and they performed some poetic functions in the work.

The novel "Eternal Wandering" is written in a unique style. The events of the novel are not visually related. That is why the reader has a bit of trouble finding the main character. The main character 
of the novel is a bootlegger, a curse that is cursed by a blessed man, Jesus. In the novel, cursed boots are displayed in different peoples and in different forms. The Gobi Desert Center for Human Perfection, with the aim of creating a perfect, immortal human being with a variety of genetic combinations, is a legend that has been cursed by thousands of years ago, as if the ethics of the bicycle have not disappeared until the end of the world. Ideally, they would spend millions and millions of dollars to find the genes of immortality and create an immortal human being, forgetting that life in this world is in fact the terrible punishment of the creator, and that the untimely departure of this world is an incredible happiness. Witchcraft is not following the path that God has made. The basic idea of the novel is that the violation of the laws of the Creator can lead to widespread destruction, which will eventually lead to human tragedy and that man will never be a perfect creature."

The narrative from the Eternal Wanderer serves to reveal the distinction between living as a real wanderer and creating a gene for humanity that lives in modern times and that both are ineffective.

According to legend, Jesus was taken away by forces to execute him. He was exhausted and tired because of the great suffering Jesus suffered. When he wants to rest on the wall of the boots for a little rest, he pushes Jesus (pbuh) so that the soldiers do not doubt me as he leans against my wall(Çağlayan, Şak, Karymshakov, Çaglayan, \& Sak, 2012).

"And he looks at the boots and says:

- Get up and be fluent!

"Now you have been condemned until the day of judgment." "And what you do is nothing, nothing, nothing."

In time, Jesus (pbuh) is the messenger of God on earth, and all who oppose him will be punished. The boots are also expelled by people of their country.

This narrative from the novel The Eternal Wreck has served as an important poetic function for the novel's plot. Each state, after gaining its independence, has its own values, customs, traditions and spiritual heritage. At the same time, this dramatic event will not only have an impact on the lives of people but also in the field of fiction. Our creators have begun to use elements of folklore in fiction. Feeding folklore varies from writer to writer. The influence of folklore is evident in the work of some artists. This is evident in the use of storytelling, fairy tales, the use of proverbs and sayings by the writers or poets, and the use of epigraphs or narratives in the work. There are artists whose folklore is not immediately apparent in their works. The elements of folklore by the artist are evident in the essence and content of the work. Uzbek author Isajon Sultan is one of such artists. The novel 'Eternal Wanderer' differs from novels written in Uzbek prose. His style of writing is similar to that of Pablo Kaolo's "Alchemist" and Camu's "Jarayon". In the foregoing masterpieces of world literature, most of the human psyche is described, describing a European person. His experiences are recorded. Even in "Eternal Wanderer" the image of the soul is stirring up with the heroic mind, but it combines elements of folklore with the folk and national diversity of the work. The role of development in the composition of fiction has been studied by literary scholars, but such studies are not very popular. As we know, the stories tell us about events in life. The narratives often portray the lives of real historical figures. The literary critic B.Sarimsakov commented: "... the stories tell about the events of the past, people who have lived long ago."

The narration in the novel "The Eternal Witch" depicts the murder of a historical figure Jesus (pbuh). This novel is reminiscent of European novels, but it is based on the synthesis of the literary traditions of the East and the West. Postmodernism in literary studies is the most Western literary method. Although Isajon Sultan wrote the novel "Eternal Wandering" in a postmodern form, it reflects Orientalism, oriental spirit, and oriental aesthetic expression. The essence of witchcraft reveals human error and degradation in the way of life. In the novel, human rejection of their own desires is seen in their rejection of their God and their opposition to him and his creations. The narration and subsequent events in the work are interrelated. The boots touched by Jesus (pbuh) are portrayed as a symbol of humanity that has lost its way in life and cannot understand what it does. Etikdoz is an eternal wanderer in the novel. His address is accurate, but he does not know the directions. He did not know what route to his destination and which one weighed heavily(Hing, 1997; Sobirov, 2018). 


\section{THEORITICAL BACKGROUND}

The novel is a philosophical novel and has been a very interesting and readable tool for an international reader who is absorbed in its content and plot.

Nature and man are always in common. They complement each other. In both fiction, these two are interpreted. Every animal and plant created by nature is a sacred blessing to mankind. The Indian cow is a sacred animal, a wolf in the Turkic people, a cat and an Egyptian. Animals that were considered sacred in the peoples were treated with rudeness. In the Turkic peoples, birds were also considered as symbolic or symbolic means. In Uzbek people the bird swallows. People will not hurt him. As our ancestors admit, the swallow pours nesting and blessing children in beautiful, peaceful homes. If it slows down, it rains. When a hacker or owl walks into an apartment, a misfortune occurs. They are told to drive as soon as they arrive. Three times when the owls arrived, our grandmothers often said that we should call Murodilla, Murodilla, Murodilla. According to legend, Owl is an enchanted bird. His real name was Murodilla. When he came, he had to say his name three times. The owl was happy to know my name and was flying away to "Muradinn." The book "The Eternal Witch" talks about black sparrows that have the same characteristics. These sparrows were black. Black is a symbol of evil in all nations. Whether it's fairy tales or fairy tales, the villains are depicted in black. The fact that soldiers were killed during the war was sent to their families as a "blackout", so that when a person dies, wearing black clothing does not appear to be a good color for the person.

"The branches of the trees around them were full of black sparrows, and they were staring at the crowd and boobs, looking silly, as if waiting for something."

The sparrows mentioned in the work had a long history of boots. The bicycle met a gentleman 30 years ago. The lord saw the black sparrows crowded in the surrounding branches of the tree. Unlike other birds, they neither harvested, nor did they fly, nor fly from the horns, but waited patiently for something until they had yellow eyes. He asked the child when these birds had come. At that, Hazrat looked at the boy and said, "Today is Friday, the thirteenth of the month. - Calculated something on its own. Sir. Then he looked at the boy and said, "Son, listen to me." "On the thirteenth day of the month, the black sparrows that arrive on Friday, actually carry the burden of a deadly and deadly anthrax."

In the novel, the Black Sparrow is the black part of the boots, the creatures that came to inform black fate. These creatures, represented in the work, are messengers of the fate of mankind.

The Lord mentions Friday the thirteenth of the month. In Eastern nations, Friday is a sacred day. It is a day when God created Adam. The thirteen is regarded as an unreasonable number in both the East and the West. Europeans in particular are scared of thirteen. A study of the meanings of numbers suggests that the use of numbers in conjunction with simple arithmetic meanings includes religious, philosophical, figurative, ethnic, and other meanings, and fiction has its own magic., has a charm.

One New York publisher publishes thirteen digits each year. Instead of the thirteen, it uses twelve digits instead of two. Every Friday, the thirteenth day of the month, thirteen people gather in one of the Chicago hotels to break thirteen windows in the thirteenth room. In Central Asia it is common to interpret thirteen days as an unfortunate day(Brilhante, Macedo, Nardini, Perego, \& Renso, 2013; Hammond, 2005; Muhammad et al., 2012).

But why the exact number of thirteen is not an accidental source. Isaac Sultan also quotes Friday and thirteen in his novel. According to Muslim sources, this day is considered to be a cursed day when Satan is cursed. The shoemaker also submits to the Prophet Jesus (pbuh) in submission to the devil. It was Friday, the thirteenth day of the month. He was like the devil and cursed until the Day of Judgment. The novel refers to a saint living on Tien Shan. There were many saints in our nation, and there were no saints before. Our saint understood the people who could perform a miracle, that is, when a saint turned his back on the water, and one night he went to Mecca. The saint in the work demands that a man perform a miracle, and if the saint does not show anything unusual, he threatens to kill him. Then the saint asked him to show him a sign. The visitor asks him not to know, but to show something unusual. The Saint does not know what he wants for himself, but tells him where he knows. The visitor was told by the saint how many plants grow in the spring in this mountain, but only by God, and by the clouds, to measure the nutrients of the plants, by God. There is a system in place, no one can oppose it. He also says that I cannot oppose this system of God. The saint's answer does not satisfy the visitor. Then the saint said to the visitor: "I cannot even find food for myself, so God has mercy on me and planted figs in his mouth." If this fig is dry, then look at my condition. In good health, I need the air, water and food that God has created. If my body suffers from a disease, I cannot cure myself, and immediately I pray to my Lord for healing. I will not be able to get out of it, I can not even know what it is, and I will cry out to God for the pain. Am I in this cave and eating figs is not a sign of poverty. I need God in everything - do you ask me instead of asking for a miracle?"

The visitor's expectation of a miracle from the saint was also a rebellion against God. The author enriched the content of the work through the image of saint, which is common among the people. 
Isaac quotes another narrative in the Sultan's novel. The narration in the novel is a perfect compilation of the plot, combining elements of the story that make up the compositional structure of the work, providing the widest range and color of the image of reality, proving the socio-philosophical views of the writer and deepening the ideological and aesthetic essence of the novel. . The aesthetic power embedded in the context of the narrative allows the development of the novel's plot to maintain a balance between the interpretation of events and the national-ethnographic image of the presented reality. The narrations used in the novel continued the events described in the work, helped to clarify the content and make the essence clearer. In the novel, the Prophet Moses (pbuh) and the fish tell the story that one day Moses (pbuh) and his servant took fish in a basket. When the servant tells him that there is no fish in the basket, they return and they come to the point where the fish swam. There was a trace of fish in the water. As we know, we use water to remove any traces. The water will wash away any traces. What kind of fish may remain on the beach? From this narration it is concluded that there is still a trace of the great variety in the world. Genes that do not know or understand one day will know who they are and discover why they were created. Mankind's rebellion against God is one day that will come to an end.

Each of the works used by the writer was intended to fill in some aspect of the novel's composition. The mausoleum of the writer "Baba Tortoise" served the same function for the composition of the work. According to legend, a turtle with the word Allah appears on the earth. The Amir of Straw was an ambitious person. He seeks out and finds the turtle in an attempt to turn it into his property. The Amir of Straw builds a room for this turtle. He was magnificent and the Amir had meetings in this room for various purposes. The turtle was watching them quietly. It seemed to the people that the prayers in that meeting would be answered. People from all over the world were listening to him. The tortoise stopped eating, and when he looked up one morning, he died. People don't bury it on a hill and put a banner on it. Years later, a tree sprang up from the place where the turtle was buried, and it looked as though it were dropping water from its leaves. On this tree everyone came and embroidered threads, and later one man built a mausoleum here. From this the mausoleum of "Baba Tortoise" was created. What is the symbol of a tortoise that is safe to use in the novel? The tortoise is first likened to a man who loses his fate. A person cannot escape what has been decreed for him. No matter where he lives, his fate will follow him. The psoriasis is also akin to such people at first glance. On the other hand, he is the symbol of a sinful man, but he is thus a sinner in the Hereafter. According to the legend of the turtle, it is a wise creature. Therefore we liken him to the wise man, who gained knowledge behind him. But he is a slowmoving creature that does not benefit from his knowledge.

The psalmist in this story is the symbol of Professor Zia, who has great knowledge. Professor Zia is a very powerful scholar and educated person, but no one can enjoy his knowledge.

The turtle can also be the symbol of a new human being created by Professor Zia, since the person who created the professor, who does not know who he is, is aimless. The tortoise is a creature that does not cause any harm or harm.

In the development we can see the struggle against the laws of nature. The Amir of Straw brought him from his place and put him in a cage, which resulted in the death of a tortoise at the hands of a human being, in violation of human law. His death was caused by a man. This narrative in the novel served to convey the meaning of the work vividly.

\section{LITERATURE REVIEW}

According to the legend of "Shahri Khaybar" this city was long ago but it was supposed to have disappeared during the occupation of the Chinzu tribe. Khaybar is a prosperous, prosperous, fair city. The Xangzu tribe is a symbol of ignorance. This tribe cannot defeat the people of Khaybar. It is hidden in the sense that ignorance can never overcome knowledge. When the khangzu tribe began to invade, two men from the Khaybar tribe came. One was an old man with long hair, his hair growing up to his shoulders, the other barefoot. A barefoot person comes from the sunset of the city, comes up on a hill and sits without doing anything. The second old man comes from the sunset. He rises to the top of the city's tallest shrine and prays long. Her knees are scratched. Then the city will disappear. The Khangzu tribe will not find him. The tribe will search this city for seven days, and the city will be visible after seven days. It will disappear again. No matter how much the ignorance prevails over the enlightenment, no matter how hard it works, all its deeds will become a mirage. The Khangzu tribe had a way of finding and conquering the eternal city. It was also a desire for knowledge, knowledge, access to its sources. The poetic function of this narrative for the composition of the novel is that the tribes of the city of Khaybar came from both the Khangzu and the great thinkers who have benefited mankind. But the Hangzu's direction of enlightenment was ignorant. The immortal human being discovered by Professor Zia in the novel does not serve the good. Assuming that the inventor created by the professor as a tool used in the fight against 
the enemy, in order to bring about the peace of the world, was in fact nothing but harm to humanity. Professor Ziyo realizes his mistake after a letter from his son and a letter from an eternity man. In the world, humanity spends its knowledge in two ways: both for the good and the evil. The way of good is clear, the way of evil is the path of ignorance. Everyone knows that the discovery of destructive weapons, the emergence of atomic bombs, the discovery of fighter jets are all the result of ignorance, the "wonderful miracles" that mankind has created in the world. But things that are not pleasant to them are always destroyed. The narrative presented in the work gives the reader this idea.

The most important way to get rid of witchcraft is to get knowledge and to use the spring of knowledge. One of the most pressing problems between written and oral literature is the literary intentions and poetic skills of the writer in the poetic approximation of the themes and elements of the genre of the genre, which are studied in the case of novels and narrative genres.

They use many elements of folklore in the literature, for example, in the development of the Uzbek prose, in the interpretation of the heroes' imagination and the writer's reaction to certain events. Writers' observation of art is reflected in their artistic aesthetic reflection of national values embodied in the characters of the heroes of the work.

"In any artistic work, the artist's attitude to reality and his / her personal opinion about the reality, everything written in the work is important to the reader. The importance of this relationship is not in the fact that it is based on the personal writings of individuals, but rather on the development and clarity of the artist's own attitude to reality. "

Indeed, the writer's worldview does not only fully reflect the national character of the work, its ideological orientation, and its personal attitude to events in life. Impressions about artistic perceptions of life are compared with the creative worldview, enriched with national spirit and values and then exposed to the world. The work will be interesting and understandable to the reader by its national spirit and national character.

When one of the great novels of the Uzbek literary prose was written by A. Kadyri, "The Past", people waited for this novel. A.Kadyri follows this national tradition, dresses and heroes the character of the Uzbek culture, characterizes it, and portrays the national spiritual and spiritual beauty. The novel is well-known for its folklore, and it is still popular today. The folklore in this novel has been widely explored, and the creative prose has revealed the skill of using folklore elements. In the novel "People in Fear" by the writer Lukmon Burkhan, who made a significant contribution to the modern generation, elements of folklore were also included, and they also played a poetic role in the composition of the novel. Observations show that even though the novel is a large-scale novel, there is a wide variety of folklore depending on the writer's skill. We have already seen the role of narratives in the novel composition of Isaac Sultan's novel The Eternal Wanderer. The style of the novel "People in the heat" is different from the style of the novel "Eternal Wandering". While the elements of folklore in it were the main narrative in the novel, "Eternal Wandering," we saw other elements of folklore in the novel "People in the Wind." In his novel The People in Flames, the writer has used proverbs, rituals, riddles, rituals, and rituals that have been the source of wisdom in all nations. These motives play a special role in the composition of the novel. All the articles in the novel appear in the characters' speech.

"Chinor was busy getting up to the train station without looking at the poor slopes, and he said, 'Do not let the flea bitter.' But at Ergashboy's time, the mountain's character ...

The stories in the novel are told from the Samad language. Ergashboy Samad's father. Ergash aka entered the university on the second year and left school for a reason, that is, Ergashboy left his institute with bitterness. The story uses the proverb "Do not let the flea bitter the blanket". This article is used to describe Ergash's situation in more detail. Burgas Inspiring Human Blood Ergash's home is compared to a flea blanket that bends to warm up during the cold. The articles also tell about the character of the hero in the fiction, without mentioning the customs and traditions of the people. Samad's teacher, Ali, walks into his teacher's classroom and tells him that all three quarters of Samad are "five." A teacher from Yellow says that it needs to be washed.

"Did you hear the words of the teachers? Come here... Ali went with me to the corridor. "That's right, Samadboy," he said, glaring at himself. - That said, a shot. Do not let the reputation go away. Is that correct?" 


\section{MAIN PART}

Each nation expresses its experience in articles in a compact way. The proverbs and wisdom of the people are hidden. It has a special educational value, preserving the centuries-old experience of the people.

Articles are preserved in both form and content, and have existed for many years. This genre is based on folk experience. As the proverbs express the wisdom of the people, they are manifested as the peculiar ethos of the most moral qualities of the human being, where the morality is confirmed and any defects or defects are condemned. It is said to be a blind person who does not want to go bad. This article was used twice in the work and was first used by Ali instructor as a reminder to Samad; The second time she was used by Ashur to present herself to the girls.

"The interdependence of folk proverbs with people's lives determines their national identity and at the same time their universal character. These two aspects are reflected in the theme of Uzbek national proverbs in the form of reflection of reality, in artistic and visual means and, finally, in the language".

In the works created by the Uzbek people, they reflect the traditions, customs, social, political, vital and national spirit of the Uzbek people. The articles in the novel can be classified according to their theme:

1. A character-specific article

2. An article specific to socio-cultural life

In folklore, the genre of proverbs was explored by theme. honesty, conscience, ridicule of tyrants, and so on.

The novel also uses the proverb: "You got to the right."

"There is a saying in our nation that you are on the right and you are numbered."

This article was quoted by Uncle Samad. Uncle paused to look at his neck and tell him that he was still an adult and would join the crowd. There are only 4 articles in the work. Almost all of them served to enhance the art of writing.

The origin of the work is reflected in the national spirit of the people. Some of the traditions, ceremonies and rituals of Uzbek people are mentioned in the novel "People in the heat". This method of the writer increased the internationalization of his work. There are some traditions and rituals that have not been studied. One of the heroes of the work, the beloved daughter of Mullah Mirza, thanks to her relatives and neighbors for helping her to recover from a serious illness.

There is a tradition in the Uzbek people that if a person is struck by a calamity, he or she will thank and sacrifice a sheep or give a sheep. People have been convinced that if this happens, disaster will be far from them.

"In the past, when mountain women came to the camp, they used to put their children in their asses and carry them on donkeys. When the wretched man got hurt and was crippled ... his ankle fell to his left foot. No one noticed. The boy ran to the kochunmoh, saying he was screaming and crying. "

In the Uzbek people, we have heard rumors that a young child is crying constantly or that someone is being abused or is being abused. They came to the emperors of the nation to feed them. The caretakers rolled bread into the baby's belly and put it under the pot. If the nurse says that the child is abusive, depending on the condition of the child, these rituals or rituals that have given birth to the chicken and the child are still alive. People believed in these rituals according to their beliefs. The scientist who studied such rituals in Uzbek people is Olim Kayumov.

In his research the literary researcher studied the activities of candles in our country. We have heard from the seniors: "The children today are weak, they are going to go to the doctor. If we were to get back in time they would be healed."

"That is why, without spending time, Mullah Mirza was disappointed and went straight to Gulomkhon's donkey, resting on his mouth, splashing on his mouth and returning."

Teaching and Recreation The person who came to Nurota district of Navoi region, who has a presence in all regions of Uzbekistan, probably didn't want to teach. The icons inspire people with verses of the Qur'an. It is a spiritual food for these people, and in this way people feel more fresh than before. It is stated in the hadiths that harms and insects that cling to man leave the person hearing the Qur'an reciting it. 
"After all, when that same page turned up, Mullah Ali was calling his girlfriend in a hurry to honor her guest!"

Women who recite the Koran in the Uzbek people are called the "horse-racing". This part of the novel depicts the first concerns and first acquaintances of one of the heroes of the book, Safarmurod Rider and his wife Tashbibi. He had read many books and knew many things. Women who have read many books among our people have also been given the status of 'horse' in relation to many women. In our people, people come to the table after dinner or eat and enjoy the meal. If they come to the guests, they will ask each one and then make du'aa. Blessings are on the house of the owner of the house. This custom exists in the Uzbek people, and in the European nations there is no such tradition. An elderly man of the family reads the prayer at the table. If you are a guest, you are invited to sit in the luncheon at the supper and after the meal. There is a saying in the Hadiths: "A supplication around a table will be heard", so supplication may be one of the ways in which Muslim people are sitting around a table.

"Mullah Mirza greeted everyone with his hand. "Amen," he said, seated on one of the empty chairs, "May God bless you and your home be peaceful and peaceful!"

Uzbek people have a wonderful proverb: "Golden apple, bless". A visitor does not go out without a blessing. When a person arrives, he is invoked to thank the host for all the good things he has been given.

The author draws attention to every tradition and traditions of the Uzbek people and uses them in his work in order to make the reader aware of the reality of the work.

"My mother's anxious awakening is not accidental. According to a long list of words, the sleeping person will die early without the taste of life, and the sleeping person will be lukewarm, but he will lick it."

The writer portrays a simple, sincere Uzbek woman in the work. Safarmurod is following the rider Lolakhon as she tries to follow the city girls and go into town. His wife Tashbibi said that the boy had woken up in his sleep the day before the accident. Samad's mother says, "What didn't wake up was getting worse when you woke up." A simple rural woman did not know that her husband had gone after the city women.

Unless human ideas in a literary work float, the work will not be of interest to the people nor will it be of value.

"Colorful and original images, symbols, and exaggeration are among the elements of art that provide a complete picture of the plot and composition of the work."

The customs and traditions of the people have a long history. They are inherited from generations to generations.

“- Lolahan bride raised me! Said Kalkanov's teacher's modest wife. "That day Khosiyat sister came to visit me."

It is a form of humanity to visit a sick person and ask him how he is. This tradition still exists among the Uzbek people. By asking the patient how he is, he or she is given the same amount of support and energy as possible. There is also a "sick patient" ceremony, where villagers come to visit the sick and the women come to the ceremony with their food. The patient's spirits rise from the conversation.

In this novel the writer presents a wedding ceremony. In the work the author presents two weddings. The first is the wedding ceremony of Urokboy and Lolakhans. The author describes this wedding ceremony as if the reader who is reading it feels like the wedding of both Urakboy and Lolakhon, when everyone attended the ceremony and witnessed it. The joy of Khosiyat, who was wearing the robe Safarmurod-aka, gave a speech to congratulate Chinor-aka's youth, all of which greatly enhanced the internationalization of the work. This is a familiar sight for the reader.

At the second wedding, the writer reflected on Lolakhon's inner mood. Lolakhon was a young, inquisitive woman. He wanted to have fun, but he was afraid of what others might say. The people of Lolakhon were loyal and loyal. Even Lolakhon wanted to get married again. But people did not want to understand or listen to him. The writer uses the wedding ceremony to reveal the fullness of Lolakhon's mental anguish. The novel also presents a funeral contrary to the wedding ceremony. By presenting the wedding ceremony, the author shows the Lolakhon's fake "fidelity," and the mourning ceremony reveals the fictitious "kindred" character of Uncle Urakboy. The writer correctly describes the mourning ceremony. The reader reads the book and imagines as if it were a member of Urakboy. The researcher D. Uraeva 
also researched places of use today, ranging from the genesis of mourning ceremonies used in folklore to her doctoral dissertation."

When the deceased was brought to the army from the army, his mother Khosiyat and his father Fayzulla aka described the mental state of the writer. It is common for people to mourn when they die. Funerals are also a form of mourning. The mourning ceremony in our nation is a legacy of Adam and Eve. When a person dies, his soul leaves the body, and the dead person's body is buried in the earth's honor. The burial place is also known as the "house of the dead".

In some regions of Uzbekistan, four or five people go to the cemetery the next day after the dead. It is also a form of mourning, and is said to be "home-made." The virtue of the aunt throwing herself on the dirt, on the coffin, on the floor shows the mother's inability to endure the stigma of the child. In general, any kind of mourning ceremony serves as a way to show how much you care about a person, but also to illuminate the heroic world and the human image. In the novel, Abdulla is portrayed as a hero who has nothing to do with anyone but himself a hero. His arrival at the iron coffin of the Duke and returning home a week later shows his sympathy for the family.

"Abdulla aka, traditionally, came to the door with loud shouting, 'wow my liver-hunt', 'wow in-hunt', and the two men standing next to each other did not fall from the bruises. the bones from her side, soothing with sad expressions such as "bitter fate" and "surrender to destiny," and she continued to live up to the tune of how much she loved the whole neighborhood. he should have known that he was a devoted relative."

This behavior of Abdulla-aka is hypocritical and false. Such defects have become a tradition among some of our people. There is a saying amongst our people: "There are people coming to the wedding, both to the wedding," and many mourners play their roles. Some will play the role of "amma", some will be "good" Uncle, and some will play a role. Above, Abdullah also played the role of a "kind brother." The funeral and the motive of the mourning have provided the realism and vibrancy of the plot of the work. As we have seen, among the Uzbeks there are some defects in their nature and character.

The customs and rituals used in the novel have been instrumental in giving the work an international spirit. Such elements provide a complete output of the plot and composition of the work. We have observed that Luqman Burkhan uses folklore not only to ensure that the work is popular and understandable, but also as an artistic tool to illuminate the inner spiritual realms of the novel's heroes. This helped to make the events of the work simple and intimate. As a wise nation lives, its customs and wonderful ceremonies are still alive with it.

The puzzle is epigraphized in the novel The People in the heat.

Epigraph (jun.pigraphe - note, title) - a short, usually reputable source (folklore, famous words of the famous people, etc.), which are given after the title of the work or at the beginning of its chapters, chapters. extract, a quote from the quote".

Choosing an epigraph to fit a prose in literature requires a great deal of knowledge and skill from the artist. The epigraph selected by the artist should represent the essence of the work. Luqman Burkhan in his novel The People in the Fury, "I have a horse, and it seems that the tails have a tail. Still, you will die ... laughing, "epigraphs the puzzle.

"Puzzles (" chist"- Persian," what it is ") is a poetic genre based on the use of symbols and gestures to convey the characteristics of things and events in a literal sense and to convey the audience with those words and events.

\section{DISCUSSION}

Contemporary fiction focuses more on the portrayal of the human psyche than the portrayal of social and political events. In this novel, the writer does not describe the social and political events in the society, but also his personal experiences and feelings. Why the writer of the novel chose this puzzle as an epigraph and whether the puzzle was taken in the context of the work, we will certainly answer these questions after reading the novel.

According to the essence of the riddle: "There is a horse that has a horse, its tails have a tail, and if you come, you will see them."

"The puzzles help you see the beauty of the world, enjoy the imagination and imagination. The riddles created by the Uzbek people cover all aspects of his social life and life"

The writer used this riddle to slightly change the original, and his answer is probably. Scorpio is a poisonous insect. Whoever sees him, of course, does not laugh at him. Maybe he was scared. 
The question then arises: Why did the writer change this riddle to epigraph the novel? Is there a connection between the idea of the novel and the puzzle? According to our observations, the popularity of this puzzle is not the original version, but rather the manuscript. Grandpa and grandmother make fun of this puzzle so they don't scare their grandchildren.

The answer to the riddle chosen as an epigraph is the "scorpion". As we get to know the events, characters and their characters, we can see how the text of the puzzle and its response are well-chosen.

Scorpio is symbolic and represents the bitter, pitiful, tragic part of the novel's main character Lolakhon. When a scorpion is touched by a scorpion, the story of his life and the tragic fate of the reader are just as exciting. The answer to the riddle depends directly on the main character of the work.

The text of the puzzle is a poetic tool for the heroes involved in the whole work. As we get acquainted with the plot of the novel and the spirit of the heroes, we can see that the relationships between the characters are artificial and inconsistent. Almost all of the characters in the novel point to the epigraph text, not to be good, but to look good.

It is revealed by the writer that the falsity of the heroes of the work had a bad consequence, not the appearance, but that the inner spirit played an important role in human life.

The bad consequence of human nature, that is, "laughter," is based on the combination of "I have a horse, you have tails, but you will still see a laugh". Not ", but the fact that you will die in fear. At the same time, we would like to draw attention to another feature of Abdulla's character in the novel. This hero doesn't try to look good to people. She loves her self-esteem. It always works by reason. That is why most people do not like it. But such people do not benefit or harm society. The image of Abdullo is drawn as a person who does not live up to the public.

The work presents an image of the Assyrian as opposed to such a feature. In fact, this image defines the essence of the whole work. The epigraph is also said in a manner appropriate to Assyria. In society, people who believe and act wisely often come from the outside, away from people's attention. There are people who, with their disgusting spirit, live among the people with dignity, honor and dignity. Ashur has the same spirit. The writer portrays his hero as Abdullah in a shameless and slanderous manner. The Assyrians are regarded as heroes in the eyes of their peers. As a matter of fact, most people in society value the person's appearance and make him a hero.

This hero reaches the head of Lolakhon, the main character of the novel. The worst part is that people put him on a hero who defends family honor, not because he killed a woman, which means he is a murderer. The essence of the "People in the heat" expands on rumors spread after the death of Lolakhon.

"True, true," they muttered. - There are angels in heaven. It was the angel who was thrown at someone else by the prophesying of these angels! God punished him for what he had done.

"The physical evidence that other people are a witch is a witch, and that the sick of the plague has not yet cooled, and that the day before has become more beautiful, the eyes are winking and eyebrows. started to prove it"

At the beginning, Lolakhon was a woman who became a symbol of loyalty among people. He was a beautiful angel. In one pass, he became an angel from a witch. Human beings try to decide the fate of many things without seeing them, holding hands. The people in the heat were some of the same people.

Nobody was aware of Lolakhon's thoughts and feelings. Imagine she was a young woman when she was a widow. Neither the parents nor the people of society understood it or ignored it. A year after the death of the mother of the sick Khosiyat, she decided to marry Fayzulla aka. His children disagree. However, when Fayzulla-aka gave it to his daughters, his daughters married her. People around him do not say anything about this.

The peculiarity of the work is that every hero in his or her mind thinks, thinks, and draws conclusions but it does not matter how true or false it is.

The novel reveals the spiritual world of the writer, who, according to the epigraph, does not distinguish between falsehood and truth, but in all things. The puzzle, taken as an epigraph to Luqman Burkhan's novel The People in Fear, expresses the essence of fiction and includes plot coverage. The puzzle, one of the folklore, plays a key role in uncovering the idea of the work. At all times, the study of the relationship between written literature and folklore has been relevant in literary studies. Folklore influences the enrichment of written literature. The use of folklore in the written literature and its inclusion in the art of literature has been called "folklorism" by literary scholars.

The word "folklore" was first used by the French folklorist Sebio in the 19th century, as a literary term meaning "to engage in folklore."

In the Russian literature of the 1930s, M.A.Azadovsky called folklore the use of folklore in fiction and publicism. In the 1960s, the use of the term "folklore" became widespread.

Bakhodir Sarimsokov is a literary scholar who has uncovered the essence of folklore in Uzbek literature. In his article "On the Typology of Folklore," the professor gives a great deal of insight into the term "folkloreism" and cites several examples of fiction. 
... A professional artist uses his creations according to his purpose, interests and area of knowledge. So, any folklore material that has been given for a purpose by a creator should be considered folklore rather than folklore, because it is "handled" by the artist. "

The professor's research has illustrated two types of folklore: simple and complex folklore and their use in literature. The works of modern writers also show the inclusion of elements of folklore into the literary text. Oral creativity has been the property of humanity and therefore, no matter how long, they are preserved and cherished as the spiritual wealth and eternal heritage of the people.

In Lukman Burkhan's novel The People in the Frenzy, we also encountered another motif of folklore: applause and curses in public discourse. The characters of the novel are portrayed as simple, sincere, noble, and sometimes hypocritical. The applause and curses used in his speech mainly served to reveal the character of these heroes. Applause is one of the best wishes in the genre of folklore. Most of the applause of our people is related to religious beliefs.

Appreciation mainly serves as a wish to people for good, to uplift their mood and to call for good. The Uzbek literary studies have studied the applause and the cursing and have not yet studied the individual artistic work. In this novel, we see Uzbek women being used by their natural applause and curses, as well as in men's forms that reflect their character and outlook. They differ from each other in the direction of the topic.

Fayzulla aka is described as the master of his work in the novel. When Lolakhon was a bride, she would say a very sweet word and laugh at everyone. The Uzbek people want a new bride, not a bride, but a bride. According to the tradition, after leaving the bride's house, the elderly say something like, "Go to the place where you are, not the bride, but the girl." Lolahan also wanted to stay in his home for a lifetime, and he was genuinely willing to serve the family of Iraqi people. Although Lola has been a bride for some time now, her family has been very fond of her. "Abdullah was a frequent visitor to his brother's house. Like a gentleman who leaves his outer garments on the sidewalk, he blushes out all the arrogance and gloom and greetings in a loud voice, "Where is our bride?" ?"

In the work of the writer, with these phrases, he reveals to the reader that Lolakhon is integrated into the Urakboy family. The poetic function of this applause in the work is to highlight Lolakhon's position in the Faizulla household.

"Sometimes my mom would complain that I was too tired to talk. "If you hear it, you will swallow honey and bite it.

It was Ergash, who was one of the heroes of the cursed work, and who was no longer a joke and a jerk. Ergash would deliver his speech under the sentence. The person who hears it will be able to understand it first and then will understand the essence of it. At first the honey is sweet and pleasant, and then it turns into poison. The words of the chairman in the work - Chinor Moyleev's likeness - are nettles, soft and pleasant to the nagging hand, and then itching. it has such an effect. Aunt Maisara used in her speech: "Wow, let me turn around" shows that Maysara is a child, a joke, a kind woman. Aunt Maisara used to tell her heroine. Applause and curses are used differently in the speech of men and women. The work has a tradition in Uzbek culture. It is a prayer at the table. A prayer in a clean, clean, clean place will be heard. When the heroine of the work passes to Samad Lolakhones, they are invited to the table. This is how Lolakhon's mother-in-law prays. "Let your head be made of stone" is applauded. The stone is used in the literal sense and is not the shape of it, but of its rigidity. All the appeals to the people give people spiritual strength. With the aunt blessing Samad as above, he was able to convey to the reader what was going on in his soul, such as the sadness of his mother who died. These applause and prayers of the woman show the childhood of the Uzbek people. "When Khosiyat's aunt told her that there were a lot of wars in the war, she ran away. , my child. We learn how hard it is for a mother to have a baby sting and that her baby is dead, but that she is looking forward to her ways every day. It shows the creative mother's willingness to do everything for her child, her enthusiasm. Every writer uses his creations to make his work more popular and popular. Applause and curses play an important role in ensuring the work's internationality. In the novel, the praise of the "Blessings" in the language of many heroes is widely used in the speech of our people. It is said that our elderly people will be "blessed" when everyone has a particular profession. This is one of the old traditions of the Uzbek people. The literary appeals that have been used by the people for the author's lively and convincing performance have been incorporated into fiction. The heroes of the novel speak of their culture, their culture or their culture. Folklore also has a genre of cursing against the genre of applause. If desire is best for greed, harm prevails in the curse. In addition to cursing and insulting the curse, there are also duties to wish for death. Studies say that the curse came from a special ceremony. In the novel The People in the Frenzy, the curse features everyone's character. In the speech of one of the novel's heroes, the rider Safarmurod, we see curses rather than applause. "All right," said Safarmurod, who had reached the ears of the merchant at the time, and slapped his rider on his knees. That bunny made it his own, that's all. " Tonka - This piece is used for human beings. Tonka is a person who is gentle and has a rough attitude. Safarmurod calls Abdulla. Through the image of Safarmurod, the writer created a portrait of a cheerful and sincere man of the village. Such 
people are often found among the people. In every speech he utters insulting words or curses as if they are superior to his opponent by using these words, as if they were nourishing his spiritual nourishment. Chinor aka, Ergash and Safarmurod sit down to drink together. Chinor aka and Ergash argue. Then Safarmurod says, "Stumble and die." Man is annoyed by his actions for his enemy and wishes him death, but Safarmurod was close friends with Chinor aka Ergash. Safarmurod wants his friends to die.

However, this was not true of him. Safarurod called Ergash's son "Child of a semi-scientist". The reason for this is that Ergash entered the university and quit studying because of a professor's wrongdoing. Since then, he has been called a "half-scholar". Calling Ergash's son with this analogy is also found in the speech of many Uzbeks. The creator made the phrase in Safarmurod's speech because of his haste, his inability to know where his words went, to describe the common man of the village. In the speech of Safarmurod, a friendly, simple man of the village, many curses were used in his speech. . This is the case with all peoples. However, one does not sometimes realize that there is great power and magic in the word. When one of the heroes of the book, Durbek tells Ashur that Lolakhon was sitting with someone on the couch, Durbek's brother told him, "No, goodbye! Dog! Go away! He says. As we know, "fun" is a well-used word. This word is used for joy, but Durbek's words are not meant for joy. The use of the word "dog" in human speech is very common. When Urakboy's coffin arrived, his mother Khosiyat waited every day for her son, not to believe that he had died. He believes that the death of his child was the cause of war. One day, her daughter says that her brother is alive and that he has heard from people. "These people are claiming that my father is a fugitive and has been involved in some kind of war." War is a catastrophe that plagues many people. Our ancestors and our people lived only for the sake of peace, and appreciated it. They glorified such words as "Independence", "Liberty", "Independence". War is the hope of all mankind, that the war will be eradicated and the earth will be destroyed. Aunt Auntie was also a part of this humanity. Through the Sword of the Blaze, the writer has incorporated the popular appeal of the public to make his work live, believable. When Ashur came from the army, he found out about Urakboy's death. His anger increased and he wanted to go back to the army and take revenge on those who killed Urokboy. Everybody wants to return it. "Polvonjon," someone barked. - Let the bad go, god. It was their boy's business, you are more harmless here. " There is a saying among the people: "If anyone does evil, he should not cut it off and turn it to God." "Getting worse is worse than cursing," our mothers say. "No one can do anything against God. If anyone does wrong to you, do not do him any harm, but set him up to God, and he will be punished. " By turning the enemy into a god, it also gives you the spirit to get rid of it. All the applause and curses of folklore are addressed to people in the novel The People in the heat. In the work we observed the applause and curses that occur in the speech of different peoples among couples and friends. Cheers and curses have been used in the prose works of literary literature of all time as analytical folklorism. Applause and curses in prose works serve to clarify the story, the story, the composition of the work. Because the novel depicts the life of the scorpions, the author's real-life applause is used in the heroic speech. Applause and curses in the work helped to clarify the subject matter and draw its conclusions. Applause and curses in public speech are his creations. Folk art is an inexhaustible source for every artist. Writing in the folklore helps the writer to integrate this prose into popularity and popularization. All the applause and curses in the novel condemned the betrayal, the expression of changes in the human psyche, the enhancement of the image of life in the prose, and, most importantly, the internationalization of the work of art. The internationality in the novel makes her not fall off the stage of literature. In any artistic work the spirit of that nation, the people. As novels are larger in size than other literary genres, the stories in it are also much larger. Heroes, characters, characters are the majority. In conclusion, the novel develops the characteristic features of creative characters in the novel, analyzes the socio-spiritual issues of the period as a literary image based on folk images. The reader can think about time, society, politics, life, and the future.

\section{REFERENCES}

1. Brilhante, I., Macedo, J. A., Nardini, F. M., Perego, R., \& Renso, C. (2013). Where Shall We Go Today? Planning Touristic Tours with TripBuilder. In CIKM (pp. 757-762). https://doi.org/10.1145/2505515.2505643

2. Çağlayan, E., Şak, N., Karymshakov, K., Çaglayan, E., \& Sak, N. (2012). RELATIONSHIP BETWEEN TOURISM AND ECONOMIC GROWTH: A PANEL GRANGER CAUSALITY APPROACH. Asian Economic and Financial Review, 2(5), 591-602. 
3. Hammond, R. (2005). Tourism along the Silk Road - international. Travel \& Tourism Analyst, (16), 1-56.

4. Hing, N. (1997). Contemporary tourism issues in Asia Pacific journals 1989-1996: a thematic perspective. International Journal of Contemporary Hospitality Management, 9(7), 254-269. https://doi.org/10.1108/09596119710190859

5. Jianzhong, M., \& Stuart, K. (1996). "Stone Camels and Clear Springs" The Salar's Samarkand Origins. Asian Folklore Studies, 55, 287-298.

6. Muhammad, S., Iqbal, J., Muneer, S., Jahanzeb, A., Iqbal, S. M. J., \& Saif-ur-Rehman. (2012). A Critical Review of Capital Structure Theories. Information Management and Business Review, 4(11), 553-557. Retrieved from http://search.proquest.com/docview/1326738751 accountid=14872

7. Sobirov, B. (2018). The concept of the tourist economic zone. Case of Uzbekistan. World Scientific News.

8. Song, H., \& Lin, S. (2010). Impacts of the financial and economic crisis on tourism in Asia. Journal of Travel Research, 49(1), 16-30. https://doi.org/10.1177/0047287509353190

9. Tao, H., Kaplan, D. L., \& Omenetto, F. G. (2012). Silk materials - A road to sustainable high technology. Advanced Materials. https://doi.org/10.1002/adma.201104477 